\title{
Evaluation of signal transduction pathways after transient cutaneous adenoviral gene delivery
}

\author{
Lars Steinstraesser ${ }^{1 *}$, Michael Sorkin ${ }^{1}$, Frank Jacobsen ${ }^{1}$, Sammy Al-Benna ${ }^{1}$, Marco Rainer Kesting ${ }^{2}$, \\ Andreas David Niederbichler ${ }^{3}$, Jan-Michel Otte ${ }^{4}$, Tobias Hirsch', Jadwiga Stupka', Hans-Ulrich Steinau', \\ Matthias Schulte ${ }^{1}$
}

\begin{abstract}
Background: Adenoviral vectors have provided effective methods for in vivo gene delivery in therapeutic applications. However, these vectors can induce immune responses that may severely affect the ability of vector reapplication. There is limited information about the mechanisms and signal transduction pathways involved in adenoviral recognition. For optimization of cutaneous gene therapy it is necessary to investigate molecular mechanisms of virus recognition in epidermal cells. The aim of this study was to investigate the signal transduction of the innate immunity after adenoviral DNA internalization in keratinocytes.

Methods: In vitro, keratinocytes were transfected with DNA, in the presence and absence of inhibitors for signalling molecules. In vivo, immunocompetent and athymic mice ( $n=3$ per group) were twice transduced with an Ad-vector.

Results: The results show an acute induction of type---interferon after in vitro transfection. Inhibition of PI3K, p38 MAPK, JNK and NFkappaB resulted in a decreased expression of type-l-interferon. In contrast to immunocompetent mice, athymic mice demonstrated a constant transgene expression and reduced inflammatory response in vivo.

Conclusion: The results suggest an induction of the innate immunity triggered by cytoplasm localised DNA which is mediated by PI3K-, p38 MAPK-, JNK-, NFkappaB-, JAK/STAT- and ERK1/2-dependent pathways. A stable transgene expression and a reduced inflammatory response in immunodeficient mice have been observed. These results provide potential for an effective adenoviral gene delivery into immunosupressed skin.
\end{abstract}

\section{Background}

The skin is the largest organ of the body, accounting for about fifteen percent of our body weight, and covering the entire external surface. While many believe its role is merely as an external covering, the functions of the skin are far more complex. The skin consists of three main layers - the epidermis, the dermis, and the hypodermis, each with their own function. It is the epidermis, which creates a barrier to and protects from pathogens of the outside world. This highly specialised layer is mainly composed of keratinocytes, melanocytes and dendritic cells. Its accessibility and specific anatomical and

\footnotetext{
* Correspondence: lars.steinstraesser@rub.de

'Laboratory for Molecular Oncology and Wound Healing, Department of Plastic Surgery, Operative Reference Centre for Soft Tissue Sarcomas, BG University Hospital Bergmannsheil, Ruhr University Bochum, Bochum, Germany

Full list of author information is available at the end of the article
}

biological properties make the skin a very interesting organ for in vivo and ex vivo gene therapy approaches. In case of cutaneous gene therapy, gene delivery can be easily controlled and the skin surgically excised if any side effects occur [1-3].

Keratinocytes, the predominant epidermal cell type, are responsible for establishing a physical barrier and guaranteeing the structural integrity of the epidermis [3]. As the epidermis is known to produce a variety of cytokines and growth factors, keratinocytes may also be engineered as bioreactors to secrete gene products which have local or systemic effects $[4,5]$.

In most gene therapy applications, a "normal" gene is inserted into the genome of an individuals cell or tissue to replace an "abnormal" disease-causing gene. In addition, foreign, therapeutical active genes can be introduced in order to add any not normally in the body

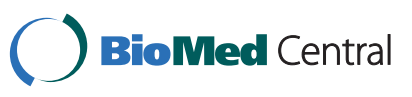

(c) 2011 Lars et al; licensee BioMed Central Ltd. This is an Open Access article distributed under the terms of the Creative Commons Attribution License (http://creativecommons.org/licenses/by/2.0), which permits unrestricted use, distribution, and reproduction in any medium, provided the original work is properly cited. 
produced metabolite. On this basis, gene therapy can be a promising tool for the treatment of a wide variety of inherited as well as acquired disease including genetically inherited skin disorders, tumours, metabolic disorders and infectious diseases (e.g. epidermolysis bullosa, xeroderma pigmentosum, ichtyosis, porphyria, squamous cell carcinomas) [6-9].

Different methods for gene delivery can be pursued, depending on the desired application. The approach used to deliver DNA into the skin will have an influence not only on the efficiency of DNA delivery, but also on the level and duration of transgene expression [10,11].

A carrier molecule called vector must be used to deliver the therapeutic gene to the target cells. Based on viral and non-viral vectors, different applications for gene delivery have been developed in the last decades $[12,13]$. For transient transduction of target cells, adenoviral vector systems possess the highest effectivity and have been used in $23.9 \%$ of the official agency sources (Gene Therapy Advisory Committee (GTAC), Recombinant DNA Advisory Committee (RAC), etc.) registered clinical trials of gene therapeutical applications for different indications, such as cancer, infectious or monogenic diseases worldwide in the last two decades [14].

Adenoviridae are non-enveloped, double stranded (ds), linear desoxyribonucleic acid (DNA) viruses with a genome of $35-40 \mathrm{~kb}$ and a particle size of 70-100 nm $[15,16]$. The adenoviral genome is well characterised and comparatively easy to manipulate. Most adenoviruses cause mild diseases in immunocompetent human adults and by deletion of crucial regions of the viral genome the vectors can be rendered replicationdefective, which increases their predictability and reduces unwanted side effects. Moreover, deleted regions of the viral genome can easily be replaced by foreign genomic material encoding the therapeutical active metabolite [17].

The process of adenoviral entry into the host is extremely efficient and has been intensively studied. Adenoviruses exhibit a wide host range in vitro and in vivo; this range was also seen in nondividing cells [18]. In addition, the well-defined and easily manipulated viral genome favours the development of adenoviral vectors for gene therapy applications [19]. This, together with information from the complete library of human DNA opened up extensive opportunities for gene therapy in medical and surgical specialities [20].

The major disadvantage of adenoviral vectors is that they can effectively induce the adaptive and innate immune response immediately after infection, leading to an induction of proinflammatory cytokines and chemokines in mice, primates and humans [21-23]. Activation of innate immunity is associated with a reduction in efficacy of gene delivery $[11,23]$. It may further cause significant inflammatory reactions leading to morbidity and mortality of the transduced host [21,22].

Newer generations of helper-dependent, gutted adenoviral vectors or adeno-associated viruses, which are depleted of almost all viral coding sequences [24], cause diminished adaptive immune responses to these vectors and improve the duration of gene transfer [25]. However, acute toxicity and diminished vector persistence provoked by the innate immune response remain the most significant barriers to clinical application of this promising technology [26]. To improve safety, efficacy and duration of adenoviral gene transfer it is necessary to explore the mechanisms by which adenoviruses trigger the innate immune response.

The detection of microbial components by pattern recognition receptors (PRRs) is one of the earliest defense mechanisms that is known to trigger innate immune responses against infections $[27,28]$. Of the many classes of molecules detected by cells as pathogen associated molecular patterns (PAMPs), nucleic acids are potent and broadly recognised [29-35]. To sense nucleic acids the immune system employs several classes of receptors, including RNA helicases that can respond to cytosolic ribonucleic acid (RNA) and DNA under certain conditions (retinoic acid-inducible gene I (RIG-I)/melanoma differentiation associated gene 5 (mda5) [35-37]), and Toll-like receptors (TLRs) that can recognise endosomal dsRNA (TLR-3) [38], singlestranded (ss)RNA (TLR-7/-8) [39-41], and hypomethylated DNA (TLR-9) [42].

Activation of TLRs occurs on the cell membrane surface (TLR-1, -2, -4, -5, -6 and -11) or within endosomal compartments (TLR-3, -7 and -9) and requires either a Myeloid differentiation primary response gene 88 (MyD88) or TIR-domain-containing adapter-inducing interferon- $\beta$ (TRIF) adapter molecules [43]. These proteins facilitate activation of downstream signalling cascades, which lead to the activation of inflammatory transcription factors, including nuclear factor-kappa B $(\mathrm{NF} \kappa \mathrm{B})$, activator protein $1(\mathrm{AP}-1)$ and interferon regulatory factors (IRF) $[43,44]$. The presence of viruses in cells is detected by TLR-3, $-7,-8$ and -9 . TLR-3 recognises double-stranded (ds) ribonucleic acid (RNA) [45], TLR-7 and TLR-8 bind single-stranded RNA $[46,47]$, whereas TLR-9 senses dsDNA which is also contained in adenoviruses [42].

Since the discovery of TLR-9, there has been a growing body of evidence that DNA derived from microbial and host cells can be recognised via a TLR-9-independent mechanism. DNA recognition in these pathways is sequence independent and occurs in the cytoplasm of the cells $[48,49]$. Different ligands, such as adenoviral, mammalian and vertebrate DNA as well as dsDNA have been characterised for TLR-independent recognition in antigen presenting cells (APCs) [50-57]. 
Recently, a DNA sensor and activator of innate immune responses has been identified and termed DNA-dependent activator of IFN-regulatory factors (DAI and also known as DLM-1 and ZBP1) [58]. Subsequent studies have shown the presence of an additional mechanism(s) for DNA-sensing and activation of the innate immune system, as well as a mechanism of negative regulation of cytosolic DNA-mediated immune responses $[59,60]$. NACHT-leucine-rich repeat-PYD containing protein 3 (NALP3) also known as cryopyrin, and its adaptor protein apoptosis-associated speck-like protein containing a CARD (ASC), regulate secretion of interleukin (IL)-1 $\beta$ in response to an adenovirus infection $[61,62]$. Inflammasome activation also occurs upon cytosolic exposure of DNA, though in this case DNAsensing was shown to be dependent on ASC and not NALP3 [61]. It remains unclear, however, as to whether the NALP3/ASC inflammasome can directly detect cytosolic DNA or if the response is triggered by another protein. Another negative regulator of the DNAmediated innate immune response, adenosine deaminase acting on RNA 1 (ADAR1), has also been reported [60]. ADAR1 is an IFN inducible protein that possesses DNA-binding domains similar to those found in DAI.

Several studies on (adenoviral) DNA induced innate immune reaction have focused on antigen presenting cells (APCs) such as dendritic cells (DCs) or macrophages $(M \Phi)$. However, information about innate immune reactions and mechanisms in virus recognition in epithelial cells, such as keratinocytes, is very limited. For optimization of cutaneous gene therapy, it is necessary to investigate the immune reaction of the predominant epidermal cell type after adenoviral challenge. Since keratinocytes represent the majority (approx. 90\%) of cells of the outermost epidermal layer [63], the aim of this study was to investigate the signal transduction of the innate immunity after adenoviral DNA internalization in this specific cell type. In addition, systemic effects of adenovirally induced immune reactions will be studied.

\section{Results}

\section{DNA internalization induced innate immune reaction}

In order to get a deeper insight into the molecular mechanisms of the innate immune system after (adenoviral) DNA internalization into keratinocytes, we decided to use a GFP-encoding adenovirus for this study. Since this generation of adenoviral vectors exhibit a high immunogenicity, this vector seemed to be an interesting tool for the investigation of signal transduction moleculess involved in adenovirus detection.

The basal mRNA levels of $18 \mathrm{~S}$ ribosomal RNA, type-Iinterferons and cytokines (IL-1 $\alpha$, IL- 6, IL- 8 and TNF- $\alpha$ ) possessed a comparable profile in $\mathrm{HaCaT}$ cells $\mathrm{HKC}$
(Figure 1A). HKC possessed significant higher levels of IL-1 $\alpha$ (20-fold, $\mathrm{p}=0.014)$ and IL-8 (5-fold, $\mathrm{p}=0.002)$ mRNA compared to $\mathrm{HaCaT}$ cells. In contrast, mRNA level of IL- 6 was detected on a significant higher level in $\mathrm{HaCaT}$ cells (3.7-fold, $\mathrm{p}=0.045$ ).

In order to get any information whether cytoplasmatic localised adenoviral DNA is capable to induce an innate immune reaction, human keratinocytes were transfected with DNA. Adenoviral DNA internalization led to a significantly increased $(\mathrm{p}=0.007)$ IFN- $\alpha$ expression $12 \mathrm{~h}$ post transfection in $\mathrm{HaCaT}$ cells. The same cells demonstrated a significant increase in IFN- $\beta$ expression (700-fold at stimulation with $3 \mu \mathrm{g} \mathrm{DNA} / \mathrm{ml}$ medium, $\mathrm{p}=0.002$ ) after stimulation for $15 \mathrm{~h}$ (Figure $1 \mathrm{~B}$ ).

Besides type-I-IFN expression, there was significant increase in expression of inflammatory cytokines, namely interleukin (IL)-1, IL-6, IL- 8 and TNF- $\alpha$ recorded in $\mathrm{HaCaT}$ cells and $\mathrm{HKC}$ with a maximal induction $24 \mathrm{~h}(\mathrm{HaCaT})$ and $12-24 \mathrm{~h}(\mathrm{HKC})$ post transfection (Figure 1B).

After detection of an adenoviral DNA induced inflammatory response in human keratinocytes it was interesting to see whether DNA from other species is also capable to activate an inflammatory reaction in these cells. RT-PCR analysis showed an increased induction of IFN- $\alpha$ in both cell types after $S$. cerevisiae (SC-) and Ad-DNA treatment (Figure 1C). Maximal induction of IFN- $\alpha$ after treatment with SC-DNA was 4.8 -fold in $\mathrm{HaCaT}$ cells and 2-fold in HKC. Transfection of calf thymus (CT-) and plasmid (P-) DNA did not show any significant effect in either cell type. The transfection with SC-DNA led to a significant increase $(\mathrm{p}<0.05)$ of IFN- $\beta$ in both cell types. In $\mathrm{HaCaT}$ cells, a 2380-fold upregulation was detected $(\mathrm{p}=0.001)$ whereas $\mathrm{HKC}$ accounted for a 11-fold increase of transcription ( $\mathrm{p}=$ 0.007). Ad-DNA stimulation of both cell types also induced an expression of IFN- $\beta$ in keratinocytes (94fold in $\mathrm{HaCaT}$ cells; 1.6-fold in HKC). No changes in IFN- $\beta$ expression of both cell types were demonstrated post CT-DNA stimulation and P-DNA induced upregulation of IFN- $\beta$ was only detected in the $\mathrm{HaCaT}$ cell line (8-fold change; $\mathrm{p}=0.012$ ).

In order to get any information about the innate immune reaction after adenoviral transduction, $\mathrm{HaCaT}$ cells were transduced with different concentrations of adenoviral vectors $\left(10^{8}-10^{10}\right.$ infection units (IU) of the GFP-encoding adenoviral vector (Figure 1D). A concentration dependent induction of IFN- $\alpha$ and IFN- $\beta$ was observed $15 \mathrm{~h}$ post transduction (IFN- $\alpha$ : 2.6 -fold $\left(10^{8}\right.$ $\mathrm{IU}, \mathrm{p}=0.056)$, 7 -fold $\left(10^{9} \mathrm{IU}, \mathrm{p}=0.02\right), 11.8$-fold $\left(10^{10}\right.$ IU, $\mathrm{p}=0.164)$; IFN- $\beta$ : 2-fold $\left(10^{8} \mathrm{IU}, \mathrm{p}=0.171\right)$, 4.2-fold ( $\left.10^{9} \mathrm{IU}, \mathrm{p}=0.046\right)$, 17.3 -fold $\left(10^{10} \mathrm{IU}, \mathrm{p}=0.0156\right)$.

An adenoviral transduction of human ex vivo full skin samples led to an induction of IFN- $\alpha$ (11-fold; 

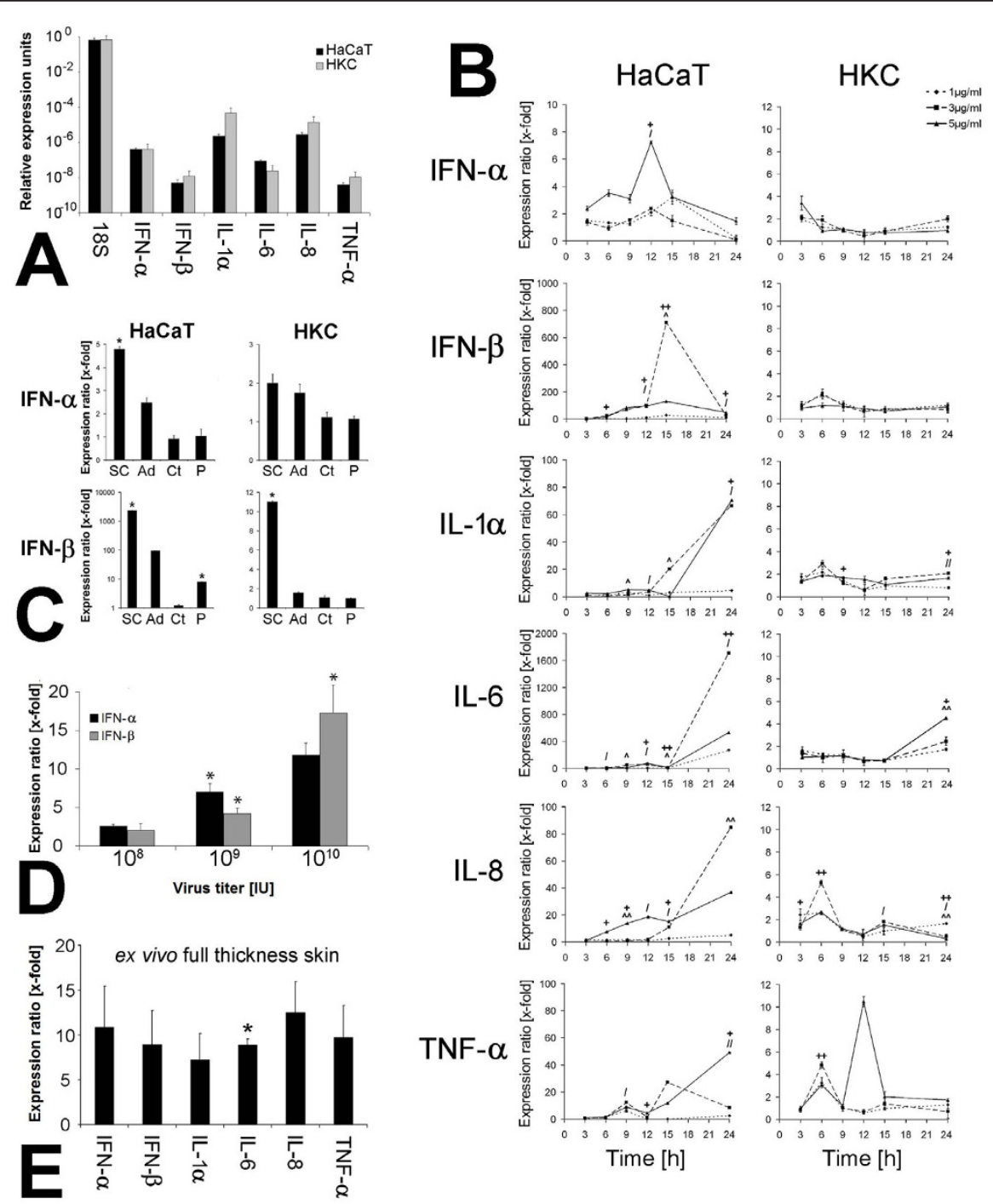

Time [h]

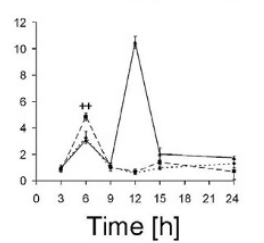

Figure 1 DNA internalization induced innate immune reaction. (A) RT-PCR analysis of type-l-interferon and cytokine basal expression in untreated HaCaT cells and HKC. (B) RT-PCR analysis of type-l-interferon and cytokine expression in HaCaT cells and HKC stimulated with different doses of adenoviral DNA (1, 3 and $5 \mu \mathrm{g}$ DNA/ml medium) for 3 to $24 \mathrm{~h}$. Results were normalized to a vehicle control (Fugene alone) $(\wedge=p<$ $0.05, \wedge \wedge=p<0.005(1 \mu \mathrm{g} \mathrm{DNA} / \mathrm{ml}$ medium) $/=\mathrm{p}<0.05, / /=\mathrm{p}<0.005(3 \mu \mathrm{g} \mathrm{DNA} / \mathrm{ml}$ medium $) ;+=\mathrm{p}<0.05,++=p<0.005(5 \mu \mathrm{g} \mathrm{DNA} / \mathrm{ml}$ medium). Data was presented as mean \pm SEM ( $n=3$ per group). (C) RT-PCR analysis of type-l-interferon expression in HaCaT cells and HKC stimulated with DNA (5 $\mathrm{\mu g}$ DNA/ml medium) from adenovirus (Ad), Saccharomyces cerevisiae (SC), calf thymus (CT) and plasmids (P). Cell were stimulated for $6 \mathrm{~h}$ (HKC) and $15 \mathrm{~h}$ (HaCaT cells). Results were normalized to a vehicle control (Fugene alone). Data was presented as mean \pm SEM ( $n=3$ per group), $\left.{ }^{*}=p<0.05\right)$. (D) RT-PCR analysis of type---interferon of HaCaT cells transduced with different concentrations of adenovirus $\left(10^{8}-10^{10} \mathrm{IU} ;{ }^{*}=p<0.05\right)$. (E) RT-PCR analysis of type---interferon and cytokine induction in human full thickness skin $12 \mathrm{~h}$ after injection of $10^{10} \mathrm{U}$ of an adenoviral type 5 vector encoding for the green fluorescent protein (GFP) $\left(^{*}=p<0.05\right)$. Results were normalised to $18 \mathrm{~S}$ ribosomal RNA (ratio: target gene/housekeeping gene) and compared to non-treated samples (vehicle control).

$\mathrm{p}=0.162) ; \mathrm{IFN}-\beta$ (10-fold; $\mathrm{p}=0.168) ; \mathrm{IL}-1 \alpha(7$-fold; $\mathrm{p}=$ 0.167); IL-6 (9-fold; $\mathrm{p}=0.001)$; IL-8 (13-fold; $\mathrm{p}=0.076$ ) and TNF- $\alpha$ (10-fold; $\mathrm{p}=0.133$ ) (Figure 1E).

\section{Involvement of Toll-like receptor family in DNA recognition}

Toll-like receptors (TLR) are among the most important receptor of innate immunity. For an investigation of the involvement of TLRs in adenoviral DNA detection. The expression levels of TLR-2, -7 and -9 were determined after transfection of DNA from different species. There was no significant change in expression of TLR-2, -7, -9 and TRIF in both cell types (Figure 2). An increased amount of MyD88 mRNA was detected in $\mathrm{HaCaT}$ cells stimulated with SC-DNA (4.2-fold; $\mathrm{p}=0.057)$, Ad-DNA (3.8-fold; $\mathrm{p}=0.041)$ and P-DNA (1.6-fold; $\mathrm{p}=0.001)$. 
A transfection of $\mathrm{HaCaT}$ cells with Ad- and SC-DNA led to an induction of DAI. Transfection with Ad-DNA led to a 4.3-fold (HaCaT, p = 0.15) and 2.79-fold (HKC, $\mathrm{p}=0.059)$ increase of DAI mRNA. Moreover, treatment of the cells with SC-DNA resulted in a stronger induction of DAI (6.4-fold ( $\mathrm{HaCaT}, \mathrm{p}=0.087$ ), 9.1-fold $(\mathrm{HKC}, \mathrm{p}=0.13)$ ).

\section{DNA recognition and signal transduction}

To get a deeper indight into signal transduction mechanisms after adenoviral challenge, different signal transduction molecules (namely NF $\kappa \mathrm{B}$, ERK2, MAPKK, p38 MAPK, JAK/STAT, JNK and PI3K were inhibited and the IFN expression was compared. Results shown in Figure 3 were normalised to the vehicle control. The IFN- $\alpha / \beta$ regulation in non-inhibited positive controls was comparable to previous experiments (Figure 1). The $\mathrm{HaCaT}$ cells and HKC demonstrated involvement of the same signal transduction pathways for IFN- $\alpha / \beta$ production (Figure 3), except for the expression of IFN- $\alpha$ in $\mathrm{HKC}$, which did not show any significant regulation of

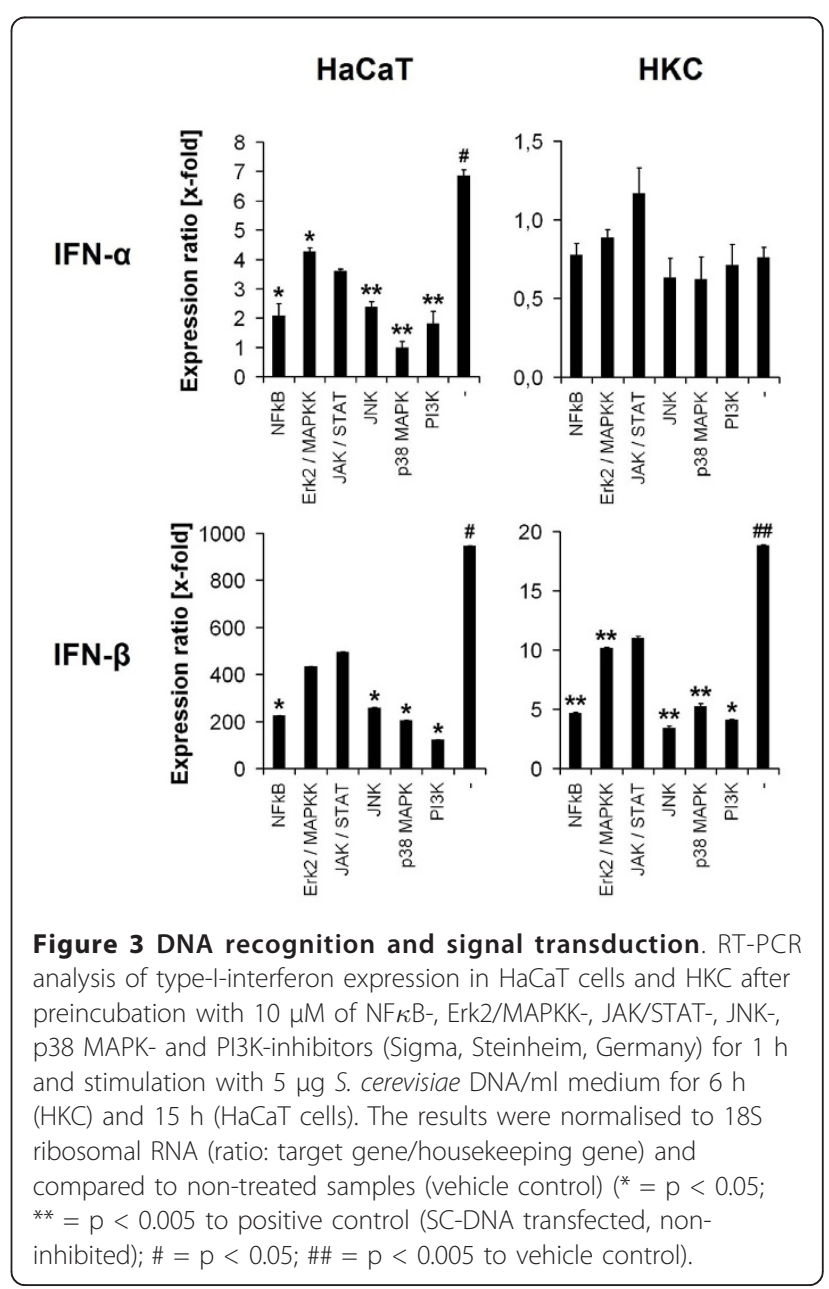

An increased amount of MyD88 mRNA was detected in HKC cells stimulated with SC-DNA (1.6-fold; $\mathrm{p}=0.03$ ) and Ad-DNA (1.2-fold; $\mathrm{p}=0.3$ ). Stimulation of $\mathrm{HaCaT}$ cells and HKC with CT-DNA and P-DNA stimulation of HKC did not show any significant differences.
Figure 2 Involvement of Toll-like receptor family in DNA recognition. RT-PCR analysis (45 cycles) for TLR-2, -7, -9, TRIF and MyD88 and DAl expression in HaCaT cells and HKC stimulated with DNA (5 $\mu \mathrm{g}$ DNA/ml medium) from adenovirus (Ad), Saccharomyces cerevisiae (SC), calf thymus (CT) and plasmids (P). Cells were stimulated for $6 \mathrm{~h}$ (HKC) and $15 \mathrm{~h}$ (HaCaT cells). Data from DAl expression was generated from cells transfected with $5 \mu \mathrm{g} \mathrm{DNA} / \mathrm{ml}$ medium. Results were normalised to $18 \mathrm{~S}$ ribosomal RNA (ratio: target gene/housekeeping gene) and compared to non-treated samples (vehicle control) $\left(^{*}=p<0.05 ;^{* *}=p<0.005\right.$ to vehicle control). 
IFN- $\alpha$ in this experiment. Figure 3 indicates the involvement of p38 MAPK, PI3K, JNK and NF $\kappa \mathrm{B}$ in triggering IFN- $\alpha / \beta$ production as the mRNA expression ratio was significantly decreased to a maximum difference of $27 \%$ compared to non-inhibited positive controls. Samples treated with Erk2/MAPKK and JAK/STAT inhibitors showed significantly reduced IFN- $\alpha / \beta$ expression from 46 to $56 \%$ compared to the positive control (Figure 3 ).

IFN- $\alpha$ mRNA levels of p38 MAPK-inhibited samples were significantly different compared to the non-inhibited positive control $(\mathrm{p}=0.002)$ in $\mathrm{HaCaT}$ cells. The lowest signals in IFN- $\beta$ expression were obtained in PI3K inhibited samples $(13 \%$ in $\mathrm{HaCaT}$ cells $(\mathrm{p}=0.05)$ and $18 \%$ in $\mathrm{HKC}(\mathrm{p}=0.01)$ compared to positive control and JNK blocked HKC (14\%, p = 0.002).

\section{Investigation of adenovirus induced immune reaction in vivo}

In vitro cell culture assays are not convenient for an investigation of systemic inflammatory effects after adenoviral challenge. To get some information about the systemic influences on vector reapplication, in vivo studies have been performed. In these experiments, immunocompetent $\left(\mathrm{SKH}-1^{\mathrm{h} / \mathrm{r}}\right)$ and $\mathrm{T}$-cell deficient athymic $\left(\right.$ Foxn- $\left.1^{\text {nu }}\right)$ mice were twice transduced with the AdGFP vector. The transgene expression and inflammatory response was measured via life imaging and qRT-PCR.

An application of $10^{10}$ IU Ad-GFP into immunocompetent mice resulted in a GFP expression detectable for 9 days with a maximum at day $2\left(1,25 \times 10^{9}\right.$ relative light units (RLU); Figure 4). A second injection of the same vector dose (AdV+AdV) as well as first transduction of two new areas $(\mathrm{PBS}+\mathrm{AdV})$ on day 14 led to an increased GFP expression for 5 days with a maximum of $2,4 \times 10^{4} \mathrm{RLU}(\mathrm{AdV}+\mathrm{AdV} ; \mathrm{p}=0.007)$ and $2 \times 10^{10} \mathrm{RLU}$ $(\mathrm{PBS}+\mathrm{AdV} ; \mathrm{p}=0.007)$ after $24 \mathrm{~h}$. An application of $10^{10}$ IU AdGFP into athymic mice resulted in a GFP expression of $4 \times 10^{8}$ RLU two days post transduction. The expression level was reduced to $6 \times 10^{3}$ RLU five days post transduction and stayed on a relatively constant level until the end of the experiment on day 19 ( $\mathrm{p}<$ 0.005). A second injection of the same vector dose into the same area did not show any changes in GFP expression. A transduction of the PBS treated (day 0) areas on day 14 resulted in an induction of GFP synthesis converging a level of $7.5 \times 10^{4}$ RLU after $24 \mathrm{~h}$. No significant changes were measured at the following time points until the end of the experiment at day 19 .

In addition to transduction with $10^{10}$ IU AdGFP, two other virus concentrations of $10^{8} \mathrm{IU}$ and $10^{9} \mathrm{IU}$ were also tested for intradermal transduction of $\mathrm{SKH}-1^{\mathrm{h} / \mathrm{r}}$ mice. The application of $10^{8}$ IU Ad-GFP did not show any detectable effects whereas the application $10^{9} \mathrm{IU}$ AdGFP lead to a GFP expression over a period of
7 days with a maximum of 1820 RLU on day 6 ( $\mathrm{p}=$ 0.082). A reapplication of the same vector dose did not show any effect (Figure 5A). In contrast, the application of $10^{10}$ IU Ad-GFP resulted in a GFP expression for 12 days with maximum at day 2 (5663 RLU, $\mathrm{p}=0.094$; Figure 5A). Reapplication of the same doses of Ad-GFP on day 14 and 28 reduced GFP expression [69\% ( $\mathrm{p}=$ $0.158)$ and $27 \%(\mathrm{p}=0.236)$ of expression on day 2] and duration (5 days; Figure 4). Blood count analysis showed a constant increase in numbers of leukocytes, granulocytes, lymphocytes and monocytes after application of $10^{10}$ IU Ad-GFP; there were no significant differences after application of lower doses (Figure 5B). RT-PCR analysis of type-I-interferon expression after transduction of athymic and immunocompetent mice exhibited a lower expression of IFN- $\alpha$ (101-fold, $\mathrm{p}=0.02\left(\mathrm{SKH}-1^{\mathrm{h}} /\right.$ $\left.{ }^{\mathrm{r}}\right)$; 1.8 -fold, $\mathrm{p}=0.09$ (Foxn-1 $\left.{ }^{\mathrm{nu}}\right)$ ) and IFN- $\beta$ (47-fold, $\mathrm{p}=$ $0.1\left(\mathrm{SKH}-1^{\mathrm{h} / \mathrm{r}}\right) ; 1.6$-fold, $\mathrm{p}=0.08\left(\right.$ Foxn- $\left.\left.1^{\mathrm{nu}}\right)\right)$ in athymic compared to immunocompetent mice (Figure 5C).

Additionally, the expression of other transcripts encoded by the adenoviral vector, was determined in this study. The viral early regions E3 and E4 are parts of the viral genome, possessing major regulatory functions. While, there was a strong decrease in GFP mRNA level in immunocompetent mice $48 \mathrm{~h}$ after second administration of the adenoviral vector, the viral early regions E3 and E4 showed an increasing expression for $120 \mathrm{~h}$ (Figure 6).

\section{Discussion}

There are a number of studies that examine molecular mechanisms of innate immunity in mice, primates and humans [11,21-23,64]. However, these studies have a propensity to only address specialised antigen-presenting cells (APCs) such as DCs or MФ [54,57] and RNA virus-induced immune reactions of APC $[46,65,66]$. In addition, data on the role of keratinocytes in innate immunity, particularly towards DNA internalization and DNA virus infection is limited. For optimization of a cutaneous gene delivery, it is critical to shed light on the molecular mechanisms a signalling pathways of the immunity of keratinocytes as they protect the body from the external environment. To address these issues, we have investigated the molecular mechanisms and signal transduction molecules involved in innate immunity towards DNA internalization into human keratinocytes. This study was performed using a replication incompetent, GFP-encoding adenovirus in order to significantly induce an innate immune response for an investigation of signal transduction molecules involved in adenovirus recognition.

This HaCaT cell line was used as it is simple to cultivate and experiments may be carried out under highly standardised and reproducible conditions [67]. Unlike 


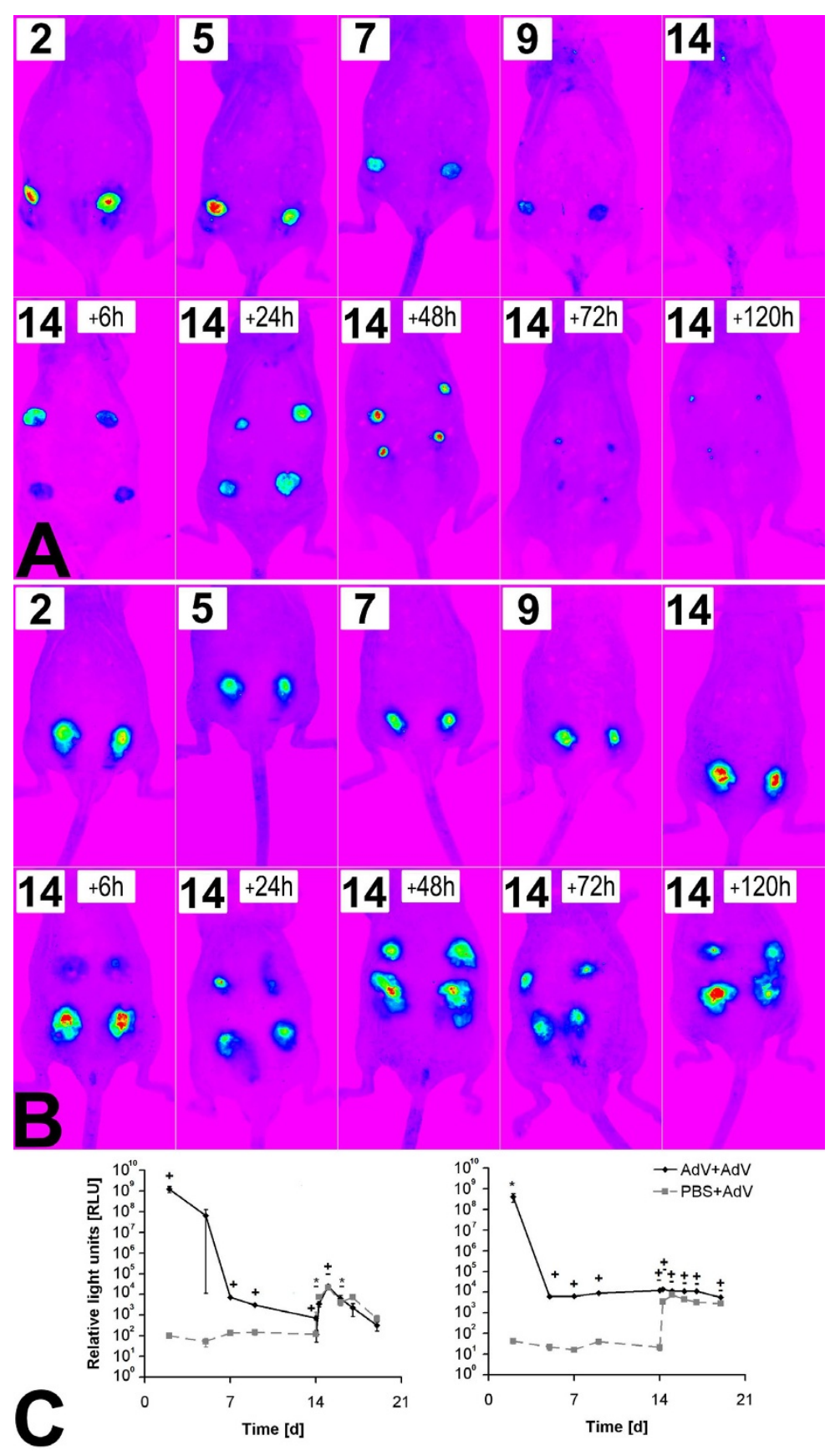

Figure 4 Investigation of adenovirus induced transgene expression in vivo. Qualitative GFP fluorescence (relative light units; RLU) detection of immunocompetent $\left(\mathrm{SKH}-1^{\mathrm{h} / \mathrm{r}}(\mathrm{A})\right)$ and athymic $\left(F o x n-1^{\mathrm{nu}}(\mathrm{B})\right)$, hairless mice at timepoints $2-19$ days after intradermal injection of $10^{10} \mathrm{IU}$ AdGFP at day 0 and reinjection of the same areas and transduction of a third area on day $14\left(^{*}=p<0.05,+=p<0.005\right.$ (AdV+AdV); $=p<$ 0.005 (PBS+AdV)). (C) Quantitative (RLU) GFP-fluorescence detection of an athymic (Foxn-1 ${ }^{\mathrm{nu}}$ ) and immunocompetent mice (SKH-1 ${ }^{\mathrm{h} / \mathrm{r}}$ ) at timepoints 2 - 19 days after intradermal injection of $10^{10} \mathrm{IU}$ Ad-GFP at day 0 and reinjection of the same areas and transduction of two new areas on day 14.

other keratinocyte cell lines, the $\mathrm{HaCaT}$ cell acts like a primary keratinocyte under many experimental conditions [68]. The spontaneously immortalised human keratinocyte $\mathrm{HaCaT}$ cell line shows almost normal differentiation and keratinization in skin models [69] and was used throughout all experiments in comparison to primary keratinocytes.

To investigate differences between the $\mathrm{HaCaT}$ cell line and primary keratinocytes, this study examined the innate immune reaction after DNA stimulation. The 

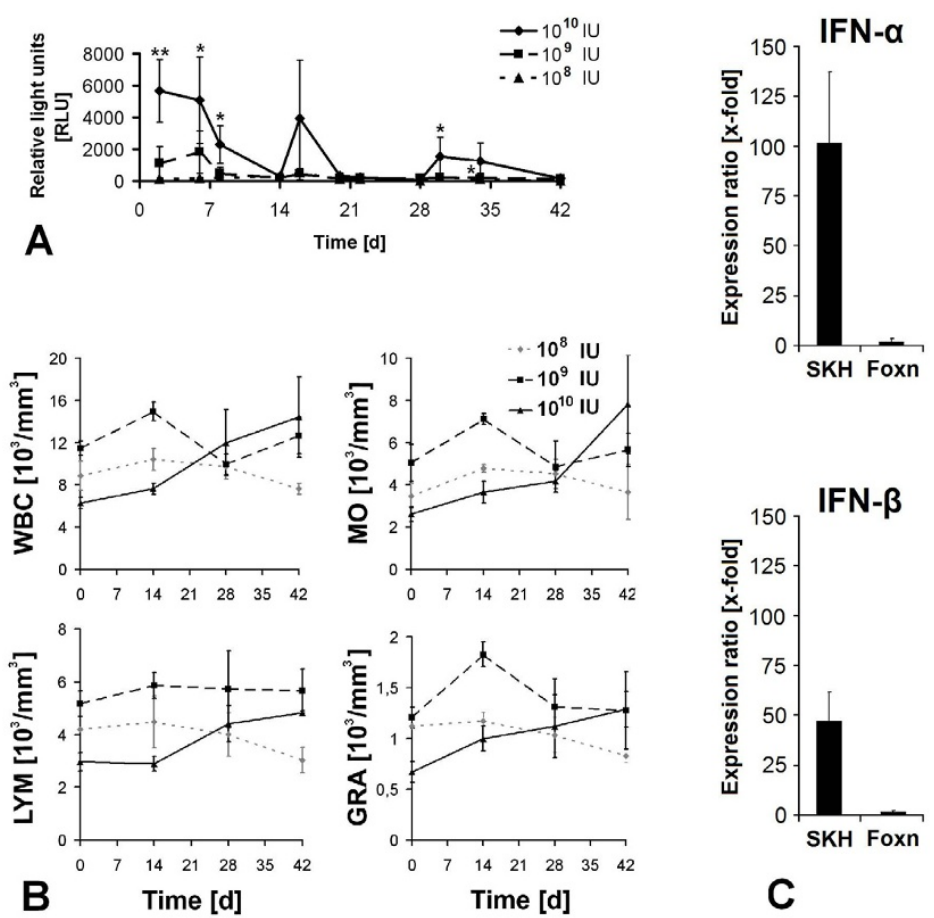

Figure 5 Investigation of adenovirus induced immune reaction in vivo. (A) Quantitative GFP fluorescence and (B) numbers of leucocytes (WBC), granulocytes (GRA), lymphocytes (LYM) and monocytes (MO) in immunocompetent, hairless mice (SKH-1 ${ }^{\mathrm{h} / r}$ ) at timepoints of 14,28 and 42 days after intradermal injection of $10^{8}-10^{10} \mathrm{IU}$ Ad-GFP. (C) RT-PCR analysis of IFN- $\alpha$ and IFN- $\beta$ expression $48 \mathrm{~h}$ after intradermal injection of $10^{10} \mathrm{IU}$ Ad-GFP in immunocompetent (SKH) and athymic (Foxn) mice. Results were normalised to an untreated control area.

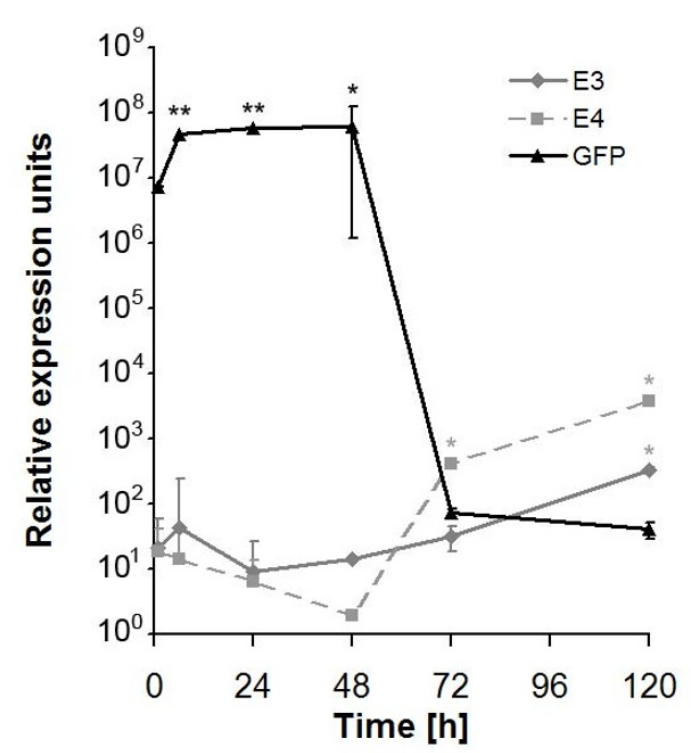

Figure 6 Adenoviral mRNA-expression in vivo. RT-PCR analysis of viral regions E3, E4 and transgene GFP expression in immunocompetent mice up to $120 \mathrm{~h}$ post transduction with $10^{10}$ IU Ad-GFP ( $\left.{ }^{*}=p<0.05,{ }^{* *}=p<0.005\right)$. Data was normalised to $18 \mathrm{~S}$ ribosomal RNA (ratio: target gene/housekeeping gene). results demonstrate the feasibility of both cell types for the investigation of innate immune responses. Cytokine expression in $\mathrm{HaCaT}$ displayed expected differences in comparison to HKC, but consistent with Köllisch et al., results were broadly comparable in chronology of interferon and cytokine induction at both cell types [70]. Any differences of induction intensity and kinetics between $\mathrm{HaCaT}$ cells and HKC were not unexpected due to altered growth conditions and the high number of passages of $\mathrm{HaCaT}$ cultures. Both cell types exhibit the same time-course with a primary induction of IFN$\alpha$ (HaCaT: $12 \mathrm{~h}$; HKC: $3 \mathrm{~h}$ ), followed by an increased IFN- $\beta$ expression (HaCaT: 15 h; HKC: 6 h) and cytokine expression (HaCaT: 24 h; HKC: 12 - 24 h).

Transduction of ex vivo full skin samples with an adenoviral vector also led to an induction of inflammatory mediators. This induction was measured on a comparable level to primary keratinocytes in vitro. This issue confirms the validity of data obtained in in vitro experiments with HKC.

Studies have described an activation of innate immunity independent of the species and sequence of internalised DNA, only the presence of nucleic acid in the cytoplasm elicits an immune reaction. The induction of type-I-interferon and cytokine synthesis during 
introduction of nucleic acids in the cytoplasm of APCs has been shown by different groups $[48,53,55,56,71]$. Limited data regarding immunogenicity of epidermal cells to different species of DNA is available. There is evidence for species independent induction of innate immunity when DNA is localised in the cytoplasm of a cell $[48,49]$ and immune induction via cytoplasmatic localised mammalian DNA has been demonstrated especially by an organism's individual DNA [53,55,56,71].

This study demonstrates a high induction of type-I-IFN by (adenoviral) DNA internalization. The results suggest that cytoplasmic localised DNA triggers induction of type-I-interferon in $\mathrm{HaCaT}$ cells and HKC. In contrast to Shirota et al., we did not find any immune reaction after stimulation with DNA from calf thymus (CT) which does not support the hypothesis of immune induction through mammalian DNA [55]. For APC, Shirota et al. showed an 800-fold induction (DCs) and a 200-fold induction $(\mathrm{M} \Phi)$ of IFN- $\beta$ in consequence of CT-DNA internalization [55]. In contrast to mammalian DNA, fungal DNA stimulation led to a significantly increased expression of type-I-IFN as well as adenoviral DNA. Taken together, the results of the present study indicate an important role of keratinocytes in innate immunity. Keratinocytes may not recognise pathogens in the same manner as APCs, but the data proposes a major role of keratinocytes in innate immune defense against pathogens.

However, once induction of innate immunity by transfection of (adenoviral) DNA was demonstrated, this study investigated signal transduction pathways involved in DNA recognition. The Toll-like receptor family is the best known PRR with TLR-9 being the unique dsDNA detection receptor for this family [43]. Downstream signalling in TLR pathways is dependent on the adapter molecules MyD88 and TRIF [72]. Studies investigating DNA/RNA recognition in different cell types propose TLR-dependent and -independent pathways for DNA/ RNA recognition in APCs $[43,50,54,56,57]$. There is limited data regarding molecular mechanisms of pathogen recognition in keratinocytes, so the involvement of TLR-9 and the adapter molecules for TLR signalling (MyD88 and TRIF) was investigated. The results indicate TLR-9 and TRIF-independent recognition of dsDNA in $\mathrm{HaCaT}$ cells and HKC. Interestingly, both cell types exhibit an upregulation of MyD88 after DNA internalization, which may denote involvement of other TLR receptors [73].

In addition to DNA recognition via TLR-9, there is also a possibility of RNA transcript or another pathogen associated molecular patterns (like zymosan, a polysaccharide from $S$. cerevisiae) induced TLR pathway induction. Therefore, this study investigated the induction of TLR-7 (viral RNA sensing receptor) and TLR-2 (zymosan detecting receptor). Evidence supports a RNA transcript and zymosan independent immune induction, since there were no changes in expression of these receptors detected. In contrast, and induction of DNA recognising receptor DAI was observed in both cell types, indicating a TLR-independent DNA recognition in keratinocytes.

Besides involvement of TLR receptor pathways in DNA recognition, this study examined participation of different effector molecules in cytokine induction. Inhibitor studies in $\mathrm{HaCaT}$ cell and $\mathrm{HKC}$ showed a 'twostep' inhibition in both cell types. On the one hand, an interferon down-regulation of 38 to $54 \%$ compared to a non-inhibited positive control was detected in consequence of blocking Erk2/MAPKK- and JAK/STAT-regulated pathways. On the other hand, inhibition of $\mathrm{NF} \kappa \mathrm{B}-$, JNK-, p38 MAPK- and PI3K-regulated pathways led to a maximal IFN down-regulation of $25 \%$ compared to noninhibited positive control. These results suggest a major participation of $\mathrm{NF} \kappa \mathrm{B}$, JNK, p38 MAPK and PI3K and also an involvement of Erk2/MAPKK and JAK/STAT in signal transduction after recognition of cytoplasmatic localised DNA. PI3K-mediated signal transduction plays a major role in IFN induction in keratinocytes. In agreement with the present study, Philpott et al. described a PI3K-mediated TNF- $\alpha$ induction pathway [74]. A major involvement of JNK, p38 MAPK and NF $\kappa \mathrm{B}$ in IFNinduction was not unexpected as these factors play a crucial role in initialization of transcription which is mediated by different pathways like TLR-, PI3K- JAK/ STAT and MAPK-cascades [75]. Secondary involvement of Erk2/MAPKK- and JAK/STAT-regulated pathways may be due to a feedback mechanism mediated by cytokine receptors in the cells. The results suggest that induction of these pathways by cytokines may be primarily initiated by DNA recognition involving PI3Kdependent signalling cascades.

The data for dose-dependence between vector dose and immune reaction for in vivo adenoviral gene delivery is supported by other studies $[54,55,57]$. The results demonstrate that local and systemic immune reactions led to increased counts of leukocytes, lymphocytes, monocytes and granulocytes in mice.

The present study exhibits a comparable time course in GFP expression post reapplication of the identical vector dose into the same or non-transduced areas. These results suggest not only a local but also a systemic reaction against adenovirus, leading to decreased intensity and duration of transgene expression. Hence, therapeutic reapplication of the vector to stabilise transgene expression may be hindered [54,57]. Adenoviral in vivo transduction into athymic mice, which exhibit a deficient $\mathrm{T}$-cell system and hence a reduced adaptive immune response, led to a stable transgene expression and reapplication of same vector doses into 
non-transduced areas showed an increase in transgene expression to the same level of areas of primary application. This, taken together with a diminished expression of type-I-interferon and proinflammatory cytokines, implies potential for effective adenoviral gene delivery into immunosuppressed skin and a future direction of our study may be to investigate inhibition of factors like type-I-interferons in order to optimise gene therapy with adenoviruses. Interestingly, there was a decrease in GFP mRNA level detected together with an increasing amount of viral region E3 and E4 mRNA (also encoded by the adenoviral vector), suggesting a gene silencing mechanism to regulate transgene expression in the tissue. Since this mechanism could not be explained yet, subsequent experiments are needed to analyse mRNA regulating effects.

The results of this study suggest an induction of the innate immunity triggered by cytoplasma localised DNA which is mediated by PI3K-, p38 MAPK-, JNK-, NF $\kappa$ B-, JAK/STAT - and ERK1/2-dependent pathways. After vector reapplication in vivo, immnocompetent mice possessed a decrease in duration and intensity in transgene expression. A stable transgene expression and a reduced inflammatory response in immunodeficient mice have been observed, suggesting opportunities for a higher efficiency of cutaneous gene delivery in immunosuppressed skin. It might be an interesting approach to influence in signal transduction cascades for an optimization of cutaneous gene delivery. Therefore, it is important to constitute any pathogen recognition receptors involved in recognition of adenoviral vectors. Since the present study did not observe any induction of TLRs 2, 7 and 9, but an induction of DAI, there is evidence for a TLR independent DNA recognition pathway in human keratinocytes. Further investigation will be required to fully describe and understand the complex mechanism in signal transduction after adenoviral challenge in human epidermal cells.

\section{Conclusion}

In summary, the results of this study suggest an TLRindependent induction of the innate immunity triggered by cytoplasm localised DNA which is mediated by PI3K-, p38 MAPK-, JNK-, NF $\kappa$ B-, JAK/STAT- and ERK1/2dependent pathways in human keratinocytes. This activation of innate immunity leads to a decrease in intensity and duration of adenovirally induced transgene expression. In contrast, a stable transgene expression and a reduced inflammatory response have been observed in immunodeficient mice. These results provide potential for an effective adenoviral gene delivery into immunosupressed skin.

\section{Methods}

\section{Keratinocyte cell culture}

Fresh human skin was obtained after abdominoplasty surgery (informed consent was given by the patient) and washed in PBS (PAA Laboratories, Coelbe, Germany). The skin was placed in a sterile petri dish and the hypodermis was excised. The skin was disinfected with Lavasept ${ }^{\circledR}$ (Braun AG, Melsungen, Germany) for $5 \mathrm{~min}$ and washed with PBS, the tissue was sliced into pieces of $1 \mathrm{~cm}^{2}$. Skin pieces were transferred into a new petri dish with the epidermal side up and the skin was completely immersed with freshly prepared $0.2 \%$ dispase-solution $(4.7 \mathrm{U} / \mathrm{ml}$, Gibco, Paisley, United Kingdom [UK]) and incubated overnight at $4^{\circ} \mathrm{C}$. The epidermis was peeled off and placed in Trypsin/EDTA-solution (0.05\%/0.02\%, Gibco, Paisley, UK) and reduced to pieces as small as possible. The pieces were incubated at $37^{\circ} \mathrm{C}$ for $20 \mathrm{~min}$ in a gently shaking (180 rpm) waterbath (GFL Burgwedel, Germany). The cell suspension was vortexed and the trypsin digestion was stopped by adding fetal bovine serum (FBS, HyClone, Logan, USA). The suspension was filtered through a 100 $\mu \mathrm{m}$ cell strainer (Becton Dickinson Heidelberg, Germany) and centrifuged at $400 \times g, 20^{\circ} \mathrm{C}$ for $5 \mathrm{~min}$. The cells were resuspended in a $5 \mathrm{ml}$ keratinocyte medium (containing 3:1 Dulbecco's Modified Eagle Medium (DMEM, Gibco, Paisley, UK), Ham's F12 (Gibco, Paisley, UK), 10\% FBS (Hyclone, Logan, USA), 1\% Penicillin/Streptomycin (ICN, Aurora, USA), 4 mM L-Glutamin (ICN, Aurora, USA), $24.3 \mu \mathrm{g} / \mathrm{ml}$ Adenine (Calbiochem, Darmstadt, Germany), $5 \mu \mathrm{g} / \mathrm{ml}$ Insulin (Sigma, St. Louis, USA), $0.8 \mu \mathrm{g} / \mathrm{ml}$ Hydrocortisone (Calbiochem, Darmstadt, Germany), 1.346 ng/ml Triiodothyronine (Sigma, St. Louis, USA), $10^{-6} \mathrm{M}$ Isoproterenol (Sigma, St. Louis, USA), 20 ng/ml hEGF (Sigma, St. Louis, USA) and counted by CASY ${ }^{\mathbb{R}}-1$ (Schärfe-System, Reutlingen, Germany). Cells were seeded at a density of 75,000 cells $/ \mathrm{cm}^{2}$ into collagen type I (Becton Dickinson Falcon, Heidelberg, Germany) precoated culture flasks. All different cell types including $\mathrm{HaCaT}$ (kindly provided by Prof. Fusenig, University of Heidelberg) cell lines were cultured at $37^{\circ} \mathrm{C}$ in humidified atmosphere of $5 \% \mathrm{CO}_{2}$. $\mathrm{HaCaT}$ cells were cultured in DMEM containing 10\% FBS (Hyclone, Logan, USA) and 1\% Penicillin/Streptomycin, medium was changed every second day.

\section{Human full skin culture}

Fresh, sterile human skin explants were obtained from three adult healthy patients (age range: 19-43 years) undergoing abdominoplasty surgery. The study was approved by the local ethics committee, and all of the patients gave written informed consent.

Immediately post excision, the skin was additionally washed in antiseptic (Octenisept, Schuelke-Mayr, 
Norderstedt, Germany) three times for ten seconds and three times in phosphate buffered saline (PBS). Subcutaneous fat was excised and the tissue was sliced into equilateral triangular pieces with sides of $2.5 \mathrm{~cm}$ length. These pieces were transferred to the base of a stainless steel chamber [76], placing the epithelial site upward. The upper part of the chamber was bolt down until the tissue was fixed, and during fixation, the skin explants were stretched to prevent contraction. Samples were cultured at the air-liquid interphase by using a 6-well plate filled with $5 \mathrm{ml}$ of culture medium; DMEM, containing $10 \% \mathrm{FBS}, 1 \%$ penicillin/streptomycin, and amphotericin B $(25 \mu \mathrm{g} / \mathrm{mL}$, PAA, Pasching, Austria). The tissue was incubated at $37^{\circ} \mathrm{C}$ in a humidified atmosphere containing $5 \% \mathrm{CO}_{2}$, and the medium was changed twice a week.

Skin explants were prepared and cultured for at least 1 week. $10^{10}$ IU Ad-GFP (green fluorescent protein) in 50 $\mu \mathrm{l}$ PBS were intradermally injected. After $12 \mathrm{~h}\left(\mathrm{n}_{\mathrm{PBS}}=3\right.$, $\mathrm{n}_{\text {Ad-GFP }}=3$ samples per group; 3 patients per group), tissue biopsy specimens were harvested for total RNA isolation.

\section{Production and purification of recombinant adenovirus}

In these studies, replication-deficient human $\Delta \mathrm{E} 1$ adenoviruses type 5 (Ad5) with inserted cytomegalovirus (CMV)-promoter driven green fluorescent protein (GFP) was used. This virus exhibits a replacement of viral early E1 gene, which is essential for viral replication, with DNA material encoding for the green fluorescent protein (GFP). The virus was propagated in HER911 cells (DMEM containing 10\% FBS and $1 \% \mathrm{P} / \mathrm{S}$ ), purified by two sequential cesium chloride $\left(\mathrm{CsCl}_{2}\right)$ gradients, and dialysed against $20 \mathrm{mM}$ Tris $/ \mathrm{HCl}, \mathrm{pH}$ 8.0. The titer was determined using an Adeno- $\mathrm{X}^{\mathrm{TM}}$ rapid titer kit (Becton Dickinson Bioscience, K1653-1, Heidelberg, Germany). Virus stocks $\left(2.11^{*} 10^{11}\right.$ infection units (IU)/ml) were stored at $-80^{\circ} \mathrm{C}$. Therefore, $10 \%$ glycerol was admixed.

\section{DNA purification}

Adenoviral (Ad5) and bacterial (plasmid; P) DNA was purified using QIAamp DNA Mini Kit (Qiagen, Hilden, Germany) following the manufacturer's instructions for blood and body fluid. For purification of DNA from Saccharomyces cerevisiae (SC-DNA) (Deutsche Hefewerke, Nürnberg, Germany), $2 \mathrm{mg}$ of cells were ground in a liquid nitrogen filled mortar. After cell disruption, $200 \mu \mathrm{l}$ buffer ATL and $25 \mu$ l Proteinase K (Qiagen, Hilden, Germany) were added. The next steps were performed according to the manufacturer's instruction. The purified DNA was eluted in a final volume of $200 \mu$ l DNase-free $\mathrm{H}_{2} \mathrm{O}$ and the concentration was photometrically determined (Eppendorf Biophotometer, Hamburg, Germany) and stored at $-80^{\circ} \mathrm{C}$ until usage. DNA samples were tested for contaminations via optical density (OD) ratio of $260 \mathrm{~nm}$ and $280 \mathrm{~nm}$; DNA samples used for transfection showeded an OD ratio of $>1.8$. Calf thymus DNA was purchased from Sigma (Sigma, Taufkirchen, Germany) and bacterial plasmid DNA was purchased from Clontech (BD Biosciences Clontech, Heidelberg, Germany).

\section{Transfection}

Cells were grown in 6-well plates until 90-100\% confluency. DNA transfection complexes were prepared according to the manufacturer's instructions (Roche Molecular Biochemicals, Mannheim, Germany). Briefly, DNA was mixed 2:5 with the Fugene ${ }^{\circledR}$ HD transfection reagent (Roche Molecular Biochemicals, Mannheim, Germany) in PCR-grade water (Roche Molecular Biochemicals, Mannheim, Germany) for $15 \mathrm{~min}$ at room temperature and then added to cells. Negative controls (vehicle controls) were treated with Fugene ${ }^{\circledR}$ HD alone without DNA. Using this agent, a transfection efficiency of $22.4 \%$ ( $\mathrm{HaCaT}$ cells) or $17.4 \%$ (HKC) has been reached using adenoviral DNA. If not mentioned otherwise, transfection experiments were performed in triplicate for each group.

\section{RNA isolation and analysis}

Cultured cells were lysed directly with buffer RLT (Qiagen, Hilden, Germany) containing 1\% (v/v) ßMercaptoethanol (Sigma, Taufkirchen, Germany). Isolation of total RNA was done using the RNeasy Mini Kit (Qiagen, Hilden, Germany), following the manufacturer's instructions for animal cells including DNA-digestion (RNase-free DNase Set, Qiagen, Hilden, Germany). Skin tissue has been taken and weighed in order not to exceed $30 \mathrm{mg}$. Tissue was stored at $-80^{\circ} \mathrm{C}$ in RNAlater until further processing. Isolation of total RNA was done using the RNeasy Mini Kit, following the manufacturer's instructions for isolation of total RNA from heart, muscle and skin including DNA-digestion (RNase-free DNase Set, Qiagen, Hilden, Germany). RNA was eluted in a final volume of $30 \mu \mathrm{l}$ RNase-free $\mathrm{H}_{2} \mathrm{O}$. The concentration of RNA was determined using the Eppendorf Biophotometer (Eppendorf, Hamburg, Germany).

\section{Reverse Transcription}

For transcription of RNA into DNA (reverse transcription) used for gene expression analysis via polymerase chain reaction (PCR), $1 \mu \mathrm{g}$ of total RNA was transcribed into cDNA using the SuperScript ${ }^{\mathrm{TM}}$ II First Strand Synthesis System for RT-PCR (Invitrogen, Karlsruhe, Germany), following the manufacturer's instructions for first-strand synthesis using random hexamer primers. cDNA was stored at $-20^{\circ} \mathrm{C}$. 


\section{Real-time PCR}

Relative Quantification of mRNA was performed in a two-step real-time RT-PCR procedure using the fluorescent dye SYBR Green I (Light Cycler FastStart DNA Master SYBR Green I, Roche, Mannheim, Germany) and a Light Cycler 1.0 (Roche, Mannheim, Germany). The first step consisted of a $\mathrm{RT}$ reaction as described above, the second step of PCR amplification with specific primers (bottom). These primer pairs were validated to generate a single PCR-product. The PCR reactions were performed with $2 \mu \mathrm{l}$ of $\mathrm{cDNA}, 0.5 \mu \mathrm{M}$ of sense and antisense primers, $3 \mathrm{mM} \mathrm{MgCl}_{2}$ and $2 \mu \mathrm{l}$ of FastStart SYBR Green reaction mix in a total volume of $20 \mu \mathrm{l}$. The cycling conditions were as follows: $95^{\circ} \mathrm{C}$ for $10 \mathrm{~min}$ at a ramp speed of $20^{\circ} \mathrm{C} / \mathrm{sec}$, 40 cycles (if not described otherwise) consisting of $94^{\circ}$ $\mathrm{C}$ for $15 \mathrm{sec}$ at a ramp speed of $20^{\circ} \mathrm{C} / \mathrm{sec}$, a primer specific annealing temperature for $10 \mathrm{sec}$ at a ramp speed of $20^{\circ} \mathrm{C} / \mathrm{sec}, 72^{\circ} \mathrm{C}$ for $10 \mathrm{sec}$ at a ramp speed of $20^{\circ} \mathrm{C} / \mathrm{sec}$, followed by a melting point analysis: $95^{\circ} \mathrm{C}$ for $0 \mathrm{sec}$ at a ramp speed of $20^{\circ} \mathrm{C} / \mathrm{sec}, 65^{\circ} \mathrm{C}$ for $15 \mathrm{sec}$ at a ramp speed of $20^{\circ} \mathrm{C} / \mathrm{sec}, 95^{\circ} \mathrm{C}$ for $0 \mathrm{sec}$ at a ramp speed of $0.1^{\circ} \mathrm{C} / \mathrm{sec}$, and finally a cooling phase: $40^{\circ} \mathrm{C}$ for $30 \mathrm{sec}$ at a ramp speed of $20^{\circ} \mathrm{C} / \mathrm{sec}$. mRNA concentrations were corrected for $18 \mathrm{~S}$ rRNA in each sample. Primer sequences for above mentioned genes are as follows: $18 \mathrm{~S}$ sense 5'-gaaactgcgaatggctcattaaa-3'; $18 \mathrm{~S}$ antisense 5'-cacagttatccaagtaggagagg-3' (annealing temperature (AT): $60^{\circ} \mathrm{C}$ ); IFN- $\alpha$ sense $5^{\prime}$-acccacagcctggataacag- $3^{\prime}$; IFN- $\alpha$ antisense $5^{\prime}$-ctctcctcctgcatcacaca-3' (AT: $60^{\circ} \mathrm{C}$ ); IFN- $\beta$ sense $5^{\prime}$-actgcctcaaggacaggatg- $3^{\prime}$; IFN- $\beta$ antisense 5'-agccaggaggttctcaacaa-3' (AT: $60^{\circ} \mathrm{C}$ ); TLR-9 sense 5'ggacctctggtactgcttcca-3'; TLR-9 antisense 5'-aagctcgttgtacacccagtct-3' (AT: $55^{\circ} \mathrm{C}$ ); MyD88 sense 5'-gagcgtttcgatgccttcat-3'; MyD88 antisense 5'-cggatcatctcctgcacaaa-3' (AT: $55^{\circ} \mathrm{C}$ ); TRIF sense $5^{\prime}$-ccagatgcaacctccactgg- $3^{\prime}$; TRIF antisense $5^{\prime}$-ctgttccgatgatgattcc-3' (AT: $55^{\circ} \mathrm{C}$ ). E3 sense $5^{\prime}$ cctgaaacacctggtccact-3' (AT: $\left.56^{\circ} \mathrm{C}\right)$; E3 antisense $5^{\prime}$ ctgggtaaactcccgaatca-3' (AT: $\left.56^{\circ} \mathrm{C}\right)$; E4 sense $5^{\prime}$-tcaggttgattcatcggtca-3' (AT: $\left.56^{\circ} \mathrm{C}\right)$; E4 antisense $5^{\prime}$-cctaggcaggagggtttttc- $3^{\prime}$ (AT: $\left.56^{\circ} \mathrm{C}\right)$; GFP sense $5^{\prime}$-acgtaaac ggccacaagttc-3' (AT: $\left.60^{\circ} \mathrm{C}\right)$; GFP antisense $5^{\prime}$-aagtcgtgctgcttcatgtg-3' (AT: $60^{\circ} \mathrm{C}$ ), DAI sense $5^{\prime}$-aaagcatggacgatttaccg-3' (AT: $\left.60^{\circ} \mathrm{C}\right)$; DAI antisense $5^{\prime}$ - atgatgttcc cgtgtccaat-3' (AT: $\left.60^{\circ} \mathrm{C}\right)$.

\section{Protein inhibition}

Prior to transfection, cells were pretreated with specific inhibitors (10 $\mu \mathrm{M}$ each) for $\mathrm{NF} \kappa \mathrm{B}$ (I $\kappa \mathrm{B}-\alpha$ inhibitor BAY117082 in DMSO), ERK1/2 (PD98059 in DMSO), p38 MAPK (SB203580 in DMSO), JNK (JNK II-inhibitor SP600125 in DMSO), PI3K (LY294002 in DMSO) and JAK-STAT (AG490 in EtOH) (Sigma, Steinheim, Germany).

\section{Animal studies}

The research protocol described below conformed to all regulations related to animal use and other German federal statutes. It was performed in compliance with the 'Guide for the Care and Use of Laboratory Animals associated with the German Animal Welfare Act. Athymic mice (Foxn-1 ${ }^{\text {nu }}$ ), which are deficient in T-cell system and provide a reduced adaptive immune reaction, were obtained from Harlan Winkelmann (Borchen, Germany) and immunocompetent, hairless "control" mice (SKH-1 ${ }^{\mathrm{h} / \mathrm{r}}$ ) were obtained from Charles River (Sulzfeld, Germany) and housed under standard conditions. In the first experiment, a total of nine immunocompetent mice were randomised into three groups with $\mathrm{n}=3$ mice. Each animal was intradermally transduced with $10^{8}-10^{10}$ infectious units (IU) AdGFP (green fluorescent protein) in $50 \mu \mathrm{l}$ PBS at two discrete areas on the back. The transgene expression was controlled by the CMV promoter for high transgene expression rates. Transgene expression was localised and quantified every second day via Kodak Imaging Station 4000 MM (Kodak GmbH, Stuttgart, Germany). 14 and 28 days after first injection a second and third virus application was performed into the same areas and into a non-treated area. Blood samples were taken from the tail vein prior to virus application (see table 1).

In the second experiment, eighteen immunocompetent and eighteen immunodeficient mice $\left(\mathrm{SKH}-1^{\mathrm{h} / \mathrm{r}}\right.$ and Foxn- $1^{\mathrm{nu}}$ ) were divided into six groups with $\mathrm{n}=3$ mice per group. Four distinct areas measuring $1 \mathrm{~cm}^{2}$ were marked on the back of each mouse. On day $0,10^{10} \mathrm{IU}$ Ad-GFP in $50 \mu \mathrm{l}$ PBS or PBS alone was intradermally injected into two areas per mouse, followed by a second injection of $10^{10}$ IU Ad-GFP into all four areas on day 14. 1, 6, 24, 48, 72 and $120 \mathrm{~h}$ after second injection, one group was euthanised by intrathoracic injection of $0.5 \mathrm{ml} \mathrm{T61}$, the transduced skin areas were excised and stored in liquid nitrogen for RNA isolation.

\section{Statistical analysis}

Differences were analysed for statistical significance with the Student's $t$-test. Error bars represent standard errors

Table 1 Inhibitors used in this study

\begin{tabular}{cr}
\hline Bay11-7085 & nuclear factor $\kappa$ B (NFkB) \\
\hline PD 98,059 & $\begin{array}{r}\text { extracellular regulated kinase 2 (Erk2); mitogen- } \\
\text { activated protein kinase kinase (MAPKK) }\end{array}$ \\
\hline SB203580 & p38 mitogen-activated protein kinase (p38 MAPK) \\
\hline LY294,002 & phosphoinositid-3-kinase (PI3K) \\
\hline $\begin{array}{c}\text { Tyrphostin AG } \\
\text { 490 }\end{array}$ & januskinase/signal transductor and aktivator of \\
transcription (JAK/STAT)
\end{tabular}


of the mean (SEM). RT-PCR analysis was displayed as expression ratio of treated and untreated (vehicle control) cells ( $\mathrm{x}$-fold expression).

\section{Abbreviations}

Ad: adenoviral; AdV: adenovirus; APC: antigen presenting cells; $\mathbf{A T}$ : annealing temperature, Ct: calf thymus; DC: dendritic cells; GFP: green fluorescent protein; HKC: human primary keratinocytes; IFN: interferon; L: interleukin; IU: infection units; P: plasmid; PBS: phosphate buffered saline: PRR: pathogen recognizing receptor; RLU: relative light unit; SC: Saccharomyces cerevisiae; TLR: toll-like receptor;

\section{Acknowledgements}

This study was financially supported by the Deutsche

Forschungsgemeinschaft (DFG). We sincerely thank Ms. Andrea Rittig for expert technical assistance.

\section{Conflict of interest statement}

The authors declare that they have no competing interests.

\section{Author details}

'Laboratory for Molecular Oncology and Wound Healing, Department of Plastic Surgery, Operative Reference Centre for Soft Tissue Sarcomas, BG University Hospital Bergmannsheil, Ruhr University Bochum, Bochum, Germany. ${ }^{2}$ Dept. of Oral and Maxillofacial Surgery, Klinikum Rechts der Isar der Technischen Universität München, München, Germany. ${ }^{3}$ Dept. of Plastic, Hand and Reconstructive Surgery, Burn Center, Medizinische Hochschule Hannover, Hannorver, Germany. ${ }^{4}$ Dept. of Gastroenterology, St. Josef Hospital, Ruhr University Bochum, Bochum, Germany.

\section{Authors' contributions}

MSC, LS and FJ conceived of and designed the study. MSC, MSO, SA-B, JS, JMO and MRK analyzed and interpreted the data. MSC and ADN drafted the paper and TH and HUS critically revised it for important intellectual content. All authors gave final approval of the version to be published.

Received: 9 June 2010 Accepted: 21 January 2011

Published: 21 January 2011

\section{References}

1. Beutler B: Innate immunity: an overview. Mol Immunol 2004, 40:845-859.

2. Christensen R, Jensen UB, Jensen TG: Cutaneous gene therapy-an update. Histochem Cell Biol 2001, 115:73-82.

3. Odland G: The structure of the skin. Biochemistry and Physiology of the Skin 1983, 3-63.

4. Luger TA, Schwarz T: Evidence for an epidermal cytokine network. J Invest Dermatol 1990, 95:100S-104S

5. Tomic-Canic M, Komine M, Freedberg IM, Blumenberg M: Epidermal signal transduction and transcription factor activation in activated keratinocytes. J Dermatol Sci 1998, 17:167-81.

6. Miller AD: Human gene therapy comes of age. Nature 1992, 357:455-60.

7. Mulligan RC: The basic science of gene therapy. Science 1993, 260:926-32.

8. Zahid S, Brownell I: Gene therapy in skin disease. J Drugs Dermatol 2007, 6:1055-8.

9. Sarma N: Gene therapy in dermatology. Indian J Dermatol 2006, 51:211-6.

10. Muruve DA: The innate immune response to adenovirus vectors. Hum Gene Ther 2004, 15:1157-1166.

11. Worgall S, Wolff G, Falck-Pedersen E, Crystal RG: Innate immune mechanisms dominate elimination of adenoviral vectors following in vivo administration. Hum Gene Ther 1997, 8:37-44.

12. Miller N, Vile R: Targeted vectors for gene therapy. FASEB J 1995, 9:190-9.

13. Robbins PD, Ghivizzani SC: Viral vectors for gene therapy. Pharmacol Ther 1998, 80:35-47

14. [http://www.wiley.com/legacy/wileychi/genmed/clinical], Accessed 17th january 2011.

15. Meier O, Greber UF: Adenovirus endocytosis. J Gene Med 2004, 6:S152-163.

16. Rux JJ, Burnett RM: Adenovirus structure. Hum Gene Ther 2004, 15:1167-1176
17. Tatsis N, Ertl HC: Adenoviruses as vaccine vectors. Mol Ther 2004 10:616-29.

18. Zhang WW: Development and application of adenoviral vectors for gene therapy of cancer. Cancer Gene Ther 1999, 6:113-38.

19. Wilson JM: Adenoviruses as gene-delivery vehicles. N Engl J Med 1996 334:1185-1187.

20. Hernandez A, Evers BM: Functional genomics: clinical effect and the evolving role of the surgeon. Arch Surg 1999, 134:1209-1215.

21. Raper SE, Chirmule N, Lee FS, Wivel NA, Bagg A, Gao GP, Wilson JM Batshaw ML: Fatal systemic inflammatory response syndrome in a ornithine transcarbamylase deficient patient following adenoviral gene transfer. Mol Genet Metab 2003, 80:148-158.

22. Schnell MA, Zhang Y, Tazelaar J, Gao GP, Yu QC, Qian R, Chen SJ, Varnavski AN, LeClair C, Raper SE, et al: Activation of innate immunity in nonhuman primates following intraportal administration of adenoviral vectors. Mol Ther 2001, 3:708-722.

23. Zhang Y, Chirmule N, Gao GP, Qian R, Croyle M, Joshi B, Tazelaar J, Wilson JM: Acute cytokine response to systemic adenoviral vectors in mice is mediated by dendritic cells and macrophages. Mol Ther 2001, 3:697-707.

24. Parks RJ, Chen L, Anton M, Sankar U, Rudnicki MA, Graham FL: A helperdependent adenovirus vector system: removal of helper virus by Cremediated excision of the viral packaging signal. PNAS 1996, 93:13565-13570.

25. Muruve DA, Cotter MJ, Zaiss AK, White LR, Liu Q, Chan T, Clark SA, Ross PJ, Meulenbroek RA, Maelandsmo GM, et al: Helper-dependent adenovirus vectors elicit intact innate but attenuated adaptive host immune responses in vivo. J Virol 2004, 78:5966-5972.

26. Brunetti-Pierri N, Palmer DJ, Beaud AL, Carey KD, Finegold M, Ng P, et al: Acute toxicity after high-dose systemic injection of helper-dependent adenoviral vectors into nonhuman primates. Hum Gene Ther 2004 15:35-46.

27. Akira S: Pathogen recognition by innate immunity and its signaling. Proc Jpn Acad Ser B Phys Biol Sci 2009, 85:143-56.

28. Janeway CA Jr, Medzhitov R: Innate immune recognition. Annu Rev Immunol 2002, 20:197-216.

29. Isaacs A, RA Cox, Rotem Z: Foreign nucleic acids as the stimulus to make interferon. Lancet 1963, 2:113-6.

30. Ishii KJ, Coban C, Kato H, Takahashi K, Torii Y, Takeshita F, Ludwig H, Sutter $G$, Suzuki $K$, Hemmi $H$, et al: A Toll-like receptor-independent antiviral response induced by double-stranded B-form DNA. Nat Immunol 2006, 7:40-8.

31. Kato H, Takeuchi O, Sato S, Yoneyama M, Yamamoto M, Matsui K Uematsu S, Jung A, Kawai T, Ishii KJ, et al: Differential roles of MDA5 and RIG-I helicases in the recognition of RNA viruses. Nature 2006, 441:101-5.

32. Kawai T, Akira S: Pathogen recognition with Toll-like receptors. Curr Opin Immunol 2005, 17:338-44

33. Stetson DB, Medzhitov R: Recognition of cytosolic DNA activates an IRF3dependent innate immune response. Immunity 2006, 24:93-103.

34. Sumpter R Jr, YM Loo, E Foy, K Li, Yoneyama M, Fujita T, Lemon SM, Gale M $\mathrm{Jr}$ : Regulating intracellular antiviral defense and permissiveness to hepatitis C virus RNA replication through a cellular RNA helicase, RIG-I. J Virol 2005, 79:2689-99.

35. Yoneyama M, Kikuchi M, Matsumoto K, Imaizumi T, Miyagishi M, Taira $\mathrm{K}$, Foy E, Loo YM, Gale M Jr, Akira S, et al: Shared and unique functions of the DExD/H-box helicases RIG-I, MDA5, and LGP2 in antiviral innate immunity. J Immunol 2005, 175:2851-8.

36. Cheng G, Zhong J, Chung J, Chisari FV: Double-stranded DNA and double-stranded RNA induce a common antiviral signaling pathway in human cells. Proc Natl Acad Sci USA 2007, 104:9035-40

37. Yoneyama M, Kikuchi $M$, Natsukawa T, Shinobu N, Imaizumi T, Miyagishi $M$, Taira K, Akira S, Fujita T: The RNA helicase RIG-I has an essential function in double-stranded RNA-induced innate antiviral responses. Nat Immunol 2004, 5:730-7.

38. Alexopoulou L, Holt AC, Medzhitov R, Flavell RA: Recognition of doublestranded RNA and activation of NF-kappaB by Toll-like receptor 3. Nature 2001, 413:732-8.

39. Diebold SS, Kaisho T, Hemmi H, Akira S, Reis e Sousa C: Innate antiviral responses by means of TLR7-mediated recognition of single-stranded RNA. Science 2004, 303:1529-31. 
40. Heil F, Hemmi H, Hochrein H, Ampenberger F, Kirschning C, Akira S Lipford G, Wagner H, Bauer S: Species-specific recognition of singlestranded RNA via toll-like receptor 7 and 8. Science 2004, 303:1526-9.

41. Lund JM, Alexopoulou L, Sato A, Karow M, Adams NC, Gale NW, Iwasaki A Flavell RA: Recognition of single-stranded RNA viruses by Toll-like receptor 7. Proc Natl Acad Sci USA 2004, 101:5598-603.

42. Hemmi H, Takeuchi O, Kawai T, Kaisho T, Sato S, Sanjo H, Matsumoto M Hoshino K, Wagner H, Takeda K, et al: A Toll-like receptor recognizes bacterial DNA. Nature 2000, 408:740-5.

43. Kawai T, Akira S: Innate immune recognition of viral infection. Nat Immunol 2006, 7:131-137.

44. Tenoever BR, Maniatis T: Parallel pathways of virus recognition. Immunity 2006, 24:510-512.

45. Alexopoulou L, Holt AC, Medzhitov R, Flavell RA: Recognition of doublestranded RNA and activation of NF-kappaB by Toll-like receptor 3. Nature 2001, 413:732-738

46. Diebold SS, Kaisho T, Hemmi H, Akira S, Reis e Sousa C: Innate antiviral responses by means of TLR7-mediated recognition of single-stranded RNA. Science 2004, 303:1529-1531.

47. Heil $F$, Hemmi H, Hochrein $H$, Ampenberger $F$, Kirschning C, Akira S, Lipford G, Wagner H, Bauer S: Species-specific recognition of singlestranded RNA via toll-like receptor 7 and 8. Science 2004, 303:1526-1529.

48. Ishii KJ, Suzuki K, Coban C, Takeshita F, Itoh Y, Matoba H, Kohn LD, Klinman DM: Genomic DNA released by dying cells induces the maturation of APCs. J Immunol 2001, 167:2602-2607.

49. Suzuki K, Mori A, Ishii KJ, Saito J, Singer DS, Klinman DM, Krause PR, Kohn LD: Activation of target-tissue immune-recognition molecules by double-stranded polynucleotides. PNAS 1999, 96:2285-2290.

50. Basner-Tschakarjan E, Gaffal E, O'Keeffe M, Tormo D, Limmer A, Wagner H, Hochrein $H$, Tüting $T$ : Adenovirus efficiently transduces plasmacytoid dendritic cells resulting in TLR9-dependent maturation and IFN-alpha production. J Gene Med 2006, 8:1300-1306.

51. Honda K, Taniguchi T: IRFs: master regulators of signalling by Toll-like receptors and cytosolic pattern-recognition receptors. Nat Rev Immunol 2006, 6:644-658

52. Kumar H, Kawai T, Kato H, Sato S, Takahashi K, Coban C, Yamamoto M, Uematsu S, Ishii KJ, Takeuchi O, et al: Essential role of IPS-1 in innate immune responses against RNA viruses. J Exp Med 2006, 203:1795-1803.

53. Martin DA, Elkon KB: Intracellular mammalian DNA stimulates myeloid dendritic cells to produce type I interferons predominantly through a toll-like receptor 9-independent pathway. Arthritis Rheum 2006, 54:951-962.

54. Nociari M, Ocheretina O, Schoggins JW, Falck-Pedersen E: Sensing infection by adenovirus: Toll-like receptor-independent viral DNA recognition signals activation of the interferon regulatory factor 3 master regulator. J Virol 2007, 81:4145-4157.

55. Shirota H, Ishii KJ, Takakuwa H, Klinman DM: Contribution of interferonbeta to the immune activation induced by double-stranded DNA. Immunology 2006, 118:302-310.

56. Yasuda K, Yu P, Kirschning CJ, Schlatter B, Schmitz F, Heit A, Bauer S, Hochrein $\mathrm{H}$, Wagner $\mathrm{H}$ : Endosomal translocation of vertebrate DNA activates dendritic cells via TLR9-dependent and -independent pathways. J Immunol 2005, 174:6129-6136.

57. Zhu J, Huang $X$, Yang $Y$ : Innate immune response to adenoviral vectors is mediated by both Toll-like receptor-dependent and -independent pathways. J Virol 2007, 81:3170-3180.

58. Takaoka A, Wang Z, Choi MK, Yanai H, Negishi H, Ban T, Lu Y, Miyagishi M, Kodama $T$, Honda $K$, et al: DAI (DLM-1/ZBP1) is a cytosolic DNA sensor and an activator of innate immune response. Nature 2007, 448:501-5.

59. Ishii K, Kawagoe T, Koyama S, Matsui K, Kumar H, Kawai T, Uematsu S, Takeuchi O, Takeshita F, Coban C, et al: TANK-binding kinase-1 delineates innate and adaptive immune responses to DNA vaccines. Nature 2008, 451:725-9.

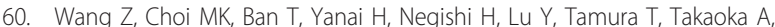
Nishikura K, Taniguchi T: Regulation of innate immune responses by DAI (DLM-1/ZBP1) and other DNA-sensing molecules. Proc Natl Acad Sci USA 2008, 105.5477-82

61. Muruve DA, Petrilli V, Zaiss AK, White LR, Clark SA, Ross PJ, Parks RJ, Tschopp J: The inflammasome recognizes cytosolic microbial and host DNA and triggers an innate immune response. Nature 2008, 452:103-7.
62. Ye Z, Ting JP: NLR, the nucleotide-binding domain leucine-rich repeat containing gene family. Curr Opin Immunol 2008, 20:3-9.

63. Elias PM, Goerke J, Friend DS: Mammalian epidermal barrier layer lipids: composition and influence on structure. J Invest Dermatol 1977, 69:535-546.

64. Higginbotham JN, Seth P, Blaese RM, Ramsey WJ: The release of inflammatory cytokines from human peripheral blood mononuclear cells in vitro following exposure to adenovirus variants and capsid. Hum Gene Ther 2002, 13:129-141.

65. López CB, Yount JS, Moran TM: Toll-like receptor-independent triggering of dendritic cell maturation by viruses. J Virol 2006, 80:3128-3134.

66. Sato M, Suemori H, Hata N, Asagiri M, Ogasawara K, Nakao K, Nakaya T, Katsuki M, Noguchi S, Tanaka N, et al: Distinct and essential roles of transcription factors IRF-3 and IRF-7 in response to viruses for IFN-alpha/ beta gene induction. Immunity 2000, 13:539-548.

67. Boukamp P, Petrussevska RT, Breitkreutz D, Hornung J, Markham A, Fusenig NE: Normal keratinization in a spontaneously immortalized aneuploid human keratinocyte cell line. J Cell Biol 1988, 106:761-771.

68. Woods JA, Traynor NJ, Brancaleon L, Moseley H: The effect of photofrin on DNA strand breaks and base oxidation in $\mathrm{HaCaT}$ keratinocytes: a comet assay study. Photochem Photobiol 2004, 79:105-113.

69. Breitkreutz D, Schoop VM, Mirancea N, Baur M, Stark HJ, Fusenig NE: Epidermal differentiation and basement membrane formation by $\mathrm{HaCaT}$ cells in surface transplants. Eur J Cell Biol 1998, 75:273-286.

70. Köllisch G, Kalali BN, Voelcker V, Wallich R, Behrendt H, Ring J, Bauer S, Jakob T, Mempel M, Ollert M: Various members of the Toll-like receptor family contribute to the innate immune response of human epidermal keratinocytes. Immunology 2005, 114:531-541.

71. Okabe Y, Kawane K, Akira S, Taniguchi T, Nagata S: Toll-like receptorindependent gene induction program activated by mammalian DNA escaped from apoptotic DNA degradation. J Exp Med 2005, 202:1333-1339.

72. Akira S, Takeda K: Toll-like receptor signalling. Nat Immunol 2004 4:499-511.

73. Akira S, Hoshino K: Myeloid differentiation factor 88-dependent and -independent pathways in toll-like receptor signaling. J Infect Dis 2003, 187(Suppl 2):S356-363

74. Philpott NJ, Nociari M, Elkon KB, Falck-Pedersen E: Adenovirus-induced maturation of dendritic cells through a PI3 kinase-mediated TNF-alpha induction pathway. PNAS 2004, 101:6200-6205.

75. [http://www.cellsignal.com], Accessed 17th january 2011.

76. Steinstraesser L, Rittig A, Gevers K, Sorkin M, Hirsch T, Kesting MR, Sand M, Al-Benna S, Langer S, Steinau HU, Jacobsen F: A human full-skin culture system for interventional studies. Eplasty 2009, 9:e5.

doi:10.1186/1471-2172-12-8

Cite this article as: Steinstraesser et al:: Evaluation of signal transduction pathways after transient cutaneous adenoviral gene delivery. BMC Immunology 2011 12:8.

\section{Submit your next manuscript to BioMed Central and take full advantage of:}

- Convenient online submission

- Thorough peer review

- No space constraints or color figure charges

- Immediate publication on acceptance

- Inclusion in PubMed, CAS, Scopus and Google Scholar

- Research which is freely available for redistribution 